\title{
Prediction of the Shear Tension Strength of Resistance Spot Welded Thin Steel Sheets from High- to Ultrahigh Strength Range
}

\author{
Kornél Májlinger ${ }^{1 *}$, Levente T. Katula', Balázs Varbai ${ }^{1}$ \\ 1 Department of Materials Science and Engineering, Faculty of Mechanical Engineering, Budapest University of Technology and \\ Economics, H-1111 Budapest, Bertalan Lajos str. 7., Hungary \\ * Corresponding author, e-mail: Majlinger.Kornel@GPK.BME.hu
}

Received: 14 July 2021, Accepted: 14 October 2021, Published online: 15 December 2021

\begin{abstract}
The tensile strength of newly developed ultra-high strength steel grades is now above $1800 \mathrm{MPa}$, and even new steel grades are currently in development. One typical welding process to join thin steels sheets is resistance spot welding (RSW). Some standardized and not standardized formulas predict the minimal shear tension strength (STS) of RSWed joints, but those formulas are less and less accurate with the higher base materials strength. Therefore, in our current research, we investigated a significant amount of STS data of the professional literature and our own experiments and recommended a new formula to predict the STS of RSWed high strength steel joints. The proposed correlation gives a better prediction than the other formulas, not only in the ultra-high strength steel range but also in the lower steel strength domain.
\end{abstract}

\section{Keywords}

resistance spot welding (RSW), advanced high strength steel (AHSS), ultra-high strength steel (UHSS), shear tension strength (STS)

\section{Introduction}

High strength steels (HSS) are gaining more and more attention and application in mechanical engineering, especially in the automotive industries [1-3]. Among high strength steels, advanced high strength (AHSS) and ultra-high strength (UHSS) steels are the most developing research areas due to their excellent mechanical strength (tensile strength $R_{m}>1500 \mathrm{MPa}$ ) and adequate ductility, which are achieved during carefully selected thermo-mechanical heat treatment processes [4]. These mechanical properties make these types of structural steels lucrative for the application in automotive industries, e.g., crash boxes, car bodies, etc. [5]. Moreover, the increasing strength leads to the reduction in wall thicknesses. The smaller wall thicknesses have allowed engineers to manufacture lighter vehicles, which is very important in terms of fuel consumption, and, thus, in environmental considerations $[6,7]$.

The most important joining process of high strength thin sheets is welding. The arc welding of AHSS and UHSS can be challenging due to the unwanted phase transformations and the possible coatings [8-11]. For these reasons, the mostly applied joining process for AHSS and UHSS thin sheets is resistance spot welding (RSW) [12, 13].
RSW welding process can be easily automated [14, 15], robotized, therefore RSW is also an optimal process for mass production. RSW is also one of the most used welding process in car body manufacturing.

To improve weld quality and welding process efficiency new types of power sources with advanced electrical controls have recently been developed. They focus on the electronic control of the welding current and, thus, the heat input. Recently, extensive research hase been done in the field of the application of different pulsed welding technologies in the case of HSS welding. Kim et al. [15] investigated different pulse profiles to improve the weld quality of CP1180 steel. They have found that the volume of the weld nugget can be increased by pulse welding, and the weldable current range can be extended compared to single pulse welding. Pulse welding can also have beneficial effects in terms of metallurgical weldability. Wintjes et al. [16] have found that pulse welding schedules can reduce liquid metal embrittlement sensitivity in the case of zinc coated TRIP1100 steels. Liu et al. [17] have found that double pulse welding with higher secondary current can lead to an enhancement in shear tension strength in the case of 
Q\&P 980 steel, due to the reduction of the partially melted zone. Multiple welding current pulses also act as a post weld heat treatment (PWHT). Stadler et al. [18] have found that the second welding current pulse remelted the center of the weld nugget of a $0.1 \mathrm{C}, 6.4 \mathrm{Mn}, 0.6 \mathrm{Si}$ (wt\%) medium $\mathrm{Mn}$-steel, leading to a recrystallization and homogenization of the initial weld microstructure, thus improving the mechanical properties. For the optimization of welding process parameters design of experiments (DoE) methods have widely been used in RSW. Soomro et al. [19] have used Taguchi DoE to optimize PWHT parameters in order to obtain the maximum peak load and failure energy in RSW of DP590 steel. Tutar et al. [20] have used Taguchi method to optimize welding parameters for the RSW of TWIP sheets. They have found that the weld current has the highest statistical effect on the tensile-shear load, followed by the welding time and the electrode force. Artificial neural network is also a useful tool in terms of optimization. Rao et al. [21] have used neural network algorithm to obtain the optimized welding parameters. With the evaluation of shear tension strength, coach-peel strength and weld nugget size, the proper parameters were selected for the RSW of DP590 steel. Beside of the these highly developing welding technologies, design and evaluation methods, the conventional weld parameter design is still based on the shear tension strength and the failure mode of the RSW joint.

The shear tension strength (STS) values found in the literature is presented on Fig. 1 (according the data of $[12,17,22-166])$ for similar and dissimilar joints.

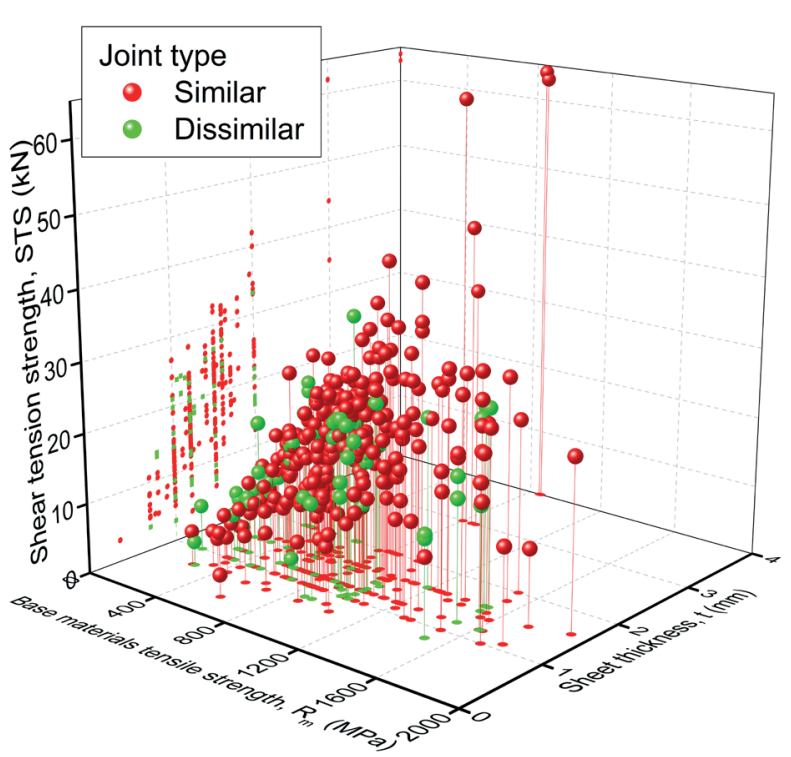

Fig. 1 STS values of RSWed high- to ultra-high strength steels in similar [18, 23-142] and dissimilar [12, 23, 25, 36, 38, 43, 50, 78, 79, 82, $87,96,98,100,101,115,119,125,143-166]$ joint configurations
To the designer to plan joint configurations some formula is needed to predict the joint strength of RSWed high strength steels. Therefore, we made our research to refine such a correlation to predict the STS value.

Our current research is a follow up paper of a previously published work "About the shear tension strength of ultra high strength steels" [22]. Here a new correlation has been proposed to predict the STS values with better accuracy in the UHSS steel range $\left(R_{m}>1340 \mathrm{MPa}\right)$ for thin sheets ( $\leq 3 \mathrm{~mm}$ thickness). Now with more experimental and more literature data an even better correlation is proposed which is applicable for the whole high strength range for steels.

\section{Equations to predict the shear tension strength}

\subsection{Different STS prediction models of the literature}

There are different classifications for normal strength steels, HSS and UHSS in different literature, for our investigations we set the boundaries according to the American AWS D8.1M standard [167] to normal strength steel $R_{m}<400 \mathrm{MPa}$, HSS $400 \mathrm{MPa}<R_{m}<800 \mathrm{MPa}$ and UHSS $R_{m}>800 \mathrm{MPa}$, respectively.

There are several equations to predict the STS values for resistance spot welded steel sheets. One approach is according to the mentioned AWS D8.1M standard [167], which gives a guide for the minimum acceptable shear tension strength values $\left(\mathrm{STS}_{\mathrm{AWS}}\right.$ ) in Eq. (1) for automotive applications.

$$
\begin{aligned}
& \operatorname{STS}_{A W S}= \\
& \frac{6.36\left(-6.36 \cdot 10^{-7} \cdot R_{m}^{2}+6.58 \cdot 10^{-4} \cdot R_{m}+1.74\right) \cdot R_{m} \cdot 4 \cdot t^{1.5}}{1000}(\mathrm{kN})
\end{aligned}
$$

In this formula $R_{m}$ is the tensile strength of the steel in $\mathrm{MPa}$, and the sheet thickness in $\mathrm{mm}$. Due to the nature of this correlation (it has maxima at $R_{m}=1340 \mathrm{MPa}$ ), the required STS $_{\text {AWS }}$ values start to decrease in the ultra-high strength steel range. It can be explained with the conservative nature of the standard, at some places of the joints even cracks are allowed. Presumably, the welding of such high-strength steel grades is challenging, and joint flaws are inevitable. Several research showed that UHSSs can be welded without defects free $[28,35,44,47,72,86-88$, 98, 101, 166].

Nevertheless, this equation is not suitable for the design of RSWed steel structures with $R_{m}>1340 \mathrm{MPa}$. To achieve the same structural strength, more spot welds are required than in case of lower strength base material. For example, 
for the welding of a $R_{m}=1500 \mathrm{MPa}$ steel the same STS is required for the joint as for a $R_{m}=1200 \mathrm{MPa}$ steel grade (see also in Figs. 2 and 3).

Investigating the professional literature and previous experiments of the authors about RSW of UHSS steels, it seems that the STS does not decrease in the $R_{m}>1340 \mathrm{MPa}$ range (Fig. 1). Therefore in our previous work [22], we modified the formula of AWS D8.1:2003 standard (Eq. (1)), to increase the minimum required STS value above the range $R_{m}>1340 \mathrm{MPa}$ (Eq. (2)).

$$
\begin{aligned}
& S T S_{\text {New1 }}= \\
& \frac{\left[3788.77-\left(-6.37 \cdot 10^{-7} \cdot R_{m}^{2}+6.58 \cdot 10^{-4} \cdot R_{m}+1.7\right)\right] \cdot R_{m} \cdot 4 \cdot t^{1.5}}{1000}(\mathrm{kN})
\end{aligned}
$$

In this formula $R_{m}$ is the tensile strength of the steel in $\mathrm{MPa}$, and $t$ the sheet thickness in $\mathrm{mm}$. This correlation gives a better prediction of the STS values in the UHSS range $R_{m}>1340 \mathrm{MPa}$. Nevertheless, there is a shortcoming of both equations namely the required STS to actual STS ratio is decreasing with increasing $R_{m}$ of the base material. This ratio can be interpreted as a kind of safety factor, but the change over the $R_{m}$ range is not beneficial for the joint design.

The authors have also investigated other standards and correlations. The ISO 14373:2015(en) [168] gives a minimal requirement for low carbon $(\mathrm{C}<0.15 \%, \mathrm{Mn}<0.6 \%)$ steels (uncoated and zink coated till $3 \mathrm{~mm}$ thicknes). Most of the UHSS steels have also a low carbon content; therefore, we investigated this correlation too (Eq. (3)).

$$
S T S_{I S O}=\frac{2.6 \cdot t \cdot d_{w} \cdot R_{m}}{1000}(k N)
$$

In this formula $d_{w}$ is the weld nugget diameter in $\mathrm{mm}$, $t$ the sheet thickness in $\mathrm{mm}$, and $R_{m}$ is the tensile strength of the steel in MPa. For this correlation, a required weld nugget diameter is needed.

Similarly, Radakovic and Tumuluru [59] defined some formulas for interstitial free (IF), transformation induced plasticity (TRIP), and dual phase steels (DP). One correlation is for predicting STS for pullout (PO) and one for interfacial (IF) fracture. Generally, the preferred fracture mode of RSWed joints is PO therefore the correlation for PO fracture (Eq. (4)) has been considered.

$$
S T S_{R \& T}=\frac{k_{P O} \cdot R_{m} \cdot t \cdot d_{w}}{1000}(k N)
$$

In this formula $k_{P O}$ is a constant with the value of $\sim 2.2$, $R_{m}$ is the tensile strength of the steel in $\mathrm{MPa}, d_{w}$ is the weld nugget diameter in $\mathrm{mm}$, and $t$ the sheet thickness in $\mathrm{mm}$. This equation is similar to the $\mathrm{STS}_{\text {ISO }}$ function; only $k_{P O}$ is lower than the constant (2.6) in Eq. (3).

In both equations (Eqs. (3) and (4)) weld nugget size is an important parameter. The minimal weld nugget diameter commonly considered at least $3.5 \cdot \sqrt{t}$ (under this value is a risk of lack of fusion defects) and the maximum nugget size $5 \cdot \sqrt{t}$ or $6 \cdot \sqrt{t}$ (above that size there is a great risk of splash) [168]. Therefore, these correlations have been investigated in the $d_{w}=3.5 \ldots 5 \cdot \sqrt{t}$ range.

\subsection{Comparison of the different STS prediction models}

The graphical representation of the previous models (Eqs. (1)-(3)) in the thin sheet range is shown in Fig. 2. The decreasing trend of $\mathrm{STS}_{\mathrm{AWS}}$ in the UHSS range $\left(R_{m}>1340 \mathrm{MPa}\right)$ is apparent. Also, there is a significant difference in the STS values of the different models with increasing $R_{m}$ and sheet thickness.

For example, in Fig. 3 the minimal STS values are plotted for the commonly available $1 \mathrm{~mm}$ sheet thickness in correlation with the tensile strength.

The model of AWS D8.1:2003 standard [167] (Eq. (1)) and the model of Radakovic and Tumuluru [59] (Eq. (3)) $d_{w}=3.5 \cdot \sqrt{t}$ give approximately the same STS values in the range of $R_{m}<800 \mathrm{MPa}$. The other models predict significant higher STS values than (Eq. (1)). For instance, in the high strength steel range (400 $\left.\mathrm{MPa}<R_{m}<800 \mathrm{MPa}\right)$,



Fig. 2 Graphical representation of the different STS prediction equations (Eqs. 1-4) in the thin sheet range 


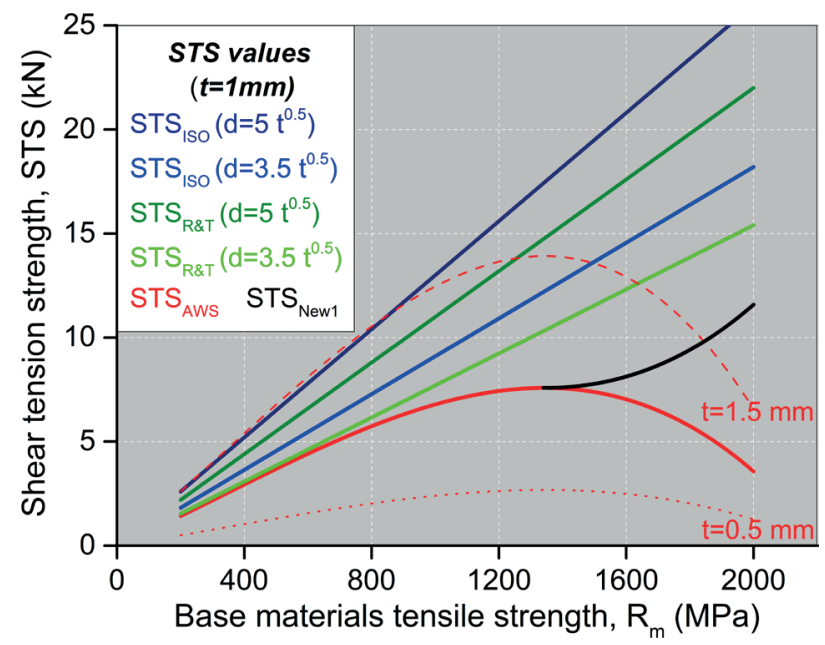

Fig. 3 Graphical representation of the different STS models (Eqs. 1-4) for $t=1 \mathrm{~mm}$ sheet thickness (except dotted lines for $t=0.5$ and $1.5 \mathrm{~mm}$ )

the predicted STS values according to the AWS standard for the sheet thickness of $1.5 \mathrm{~mm}$ are the same as the STS values according to the ISO standard with the nugget diameter $d_{w}=5 \cdot \sqrt{t}$. The difference in the UHSS range $\left(R_{m}>800 \mathrm{MPa}\right)$ is even more severe. For example, for an UHSS with $t=1 \mathrm{~mm}$ thickness and $R_{m}=1600 \mathrm{MPa}$ the $\mathrm{STS}_{\text {AWS }}=7.03 \mathrm{kN}, \mathrm{STS}_{\mathrm{New1}}=8.12 \mathrm{kN}, \mathrm{STS}_{\mathrm{R} \& \mathrm{~T}}=17.6 \mathrm{kN}$ $\left(d_{w}=5 \cdot \sqrt{t}\right)$ and $\operatorname{STS}_{\text {ISO }}=20.08 \mathrm{kN}\left(d_{w}=5 \cdot \sqrt{t}\right)$, the difference between the lowest and highest estimation is about $300 \%$ ! This difference can be even higher at higher $R_{m}$ and sheet thicknesses.

Therefore, RSW experiments were performed and evaluated together with the literature data to better correlate the STS values.

\section{RSW experiments}

To complement the STS data from the literature, weld optimizations were made in the HSS and UHSS range in similar and dissimilar combinations. With the exception of the TRIP steel, which was produced as a test production by ISD Dunaferr Ltd, the other grades were produced by the company SSAB. The main properties of the base materials are listed in Table 1. The different steel types were designated according to their minimal guaranteed tensile strength $\left(R_{m}=800-1700 \mathrm{MPa}\right)$. The trade names of the DP 800 and DP 1000 sheets of steel are Docol 800DP, Docol 1000DP, for the CP 1000 steel Docol 1000CP and for the martensitic grades $1400 \mathrm{M}, 1500 \mathrm{M}, 1700 \mathrm{M}$ are Docol 1400M, Docol 1500M, and Docol 1700M, respectively. The martensitic and bainitic wear-resistant steel grade has been designated according to its trade name as Hardox 450, where 450 is Brinell hardness of the steels.
Table 1 Main properties of the base materials used for own RSW experiments

\begin{tabular}{lcccccc}
\hline Steel grade & $\begin{array}{c}\text { Sheet } \\
\text { thickness } \\
(\mathrm{mm})\end{array}$ & CEV & $\begin{array}{c}R_{p 0.2} \\
\text { min. } \\
(\mathrm{MPa})\end{array}$ & $\begin{array}{c}R_{m} \\
\text { min. } \\
(\mathrm{MPa})\end{array}$ & $\begin{array}{c}\mathrm{A}_{80} \\
(\%)\end{array}$ & $\begin{array}{c}\text { Hardness } \\
(\text { HV10) }\end{array}$ \\
\hline TRIP 800 & 1.2 & 0.21 & n.a. & 896 & 22 & 277 \\
DP 800 & 1.2 & 0.39 & 620 & 800 & 14 & 241 \\
CP 1000 & 1.4 & 0.41 & 800 & 1000 & 6 & 300 \\
DP 1000 & 1 & 0.39 & 700 & 1000 & 10 & 305 \\
$1400 \mathrm{M}$ & 1 & 0.39 & 1150 & 1400 & 3 & 447 \\
$1500 \mathrm{M}$ & 1 & 0.37 & 1200 & 1500 & 3 & 470 \\
$1700 \mathrm{M}$ & 1 & 0.21 & 1350 & 1700 & 3 & 600 \\
Hardox450 & 1 & 0.46 & 1300 & 1820 & 4 & 475 \\
\hline
\end{tabular}

The RSW experiments were made with a P.E.I.-POINT PN25 machine at $50 \mathrm{~Hz}$ frequency (AC), with P.E.I.POINT PX 1500P control unit. The RSW welding unit had an X-type welding arm assembly, with $D=5 \mathrm{~mm}$ diameter round $\mathrm{CuCrZr}$ electrodes. Electrode force was $1.9 \mathrm{kN}$. Welds were made with a simple work schedule. The varied parameters were the welding time and welding current. Both parameters can be set from 0 to 99 as integer values. Calibration curves were measured for the welding parameters by a BF Entron WA1 Weld Analyse type current measurement unit with a Rogowski coil. According to the calibration the welding time, welding current and welding voltage can be calculated by the Eqs. (5), (6) and (7), respectively.

Welding time $=$ welding cycles $\cdot 50 / 100(s)$

Welding current $=$

$1.73+0.12 \cdot$ currrent setting of the RSW machine $(\mathrm{kA})^{(6)}$

Welding voltage $=$

$0.59+30 \cdot$ currrent setting of the RSW machine $(\mathrm{V})$

The RSW joints were optimized to achieve the highest STS value. The experiments were arranged with a central composite design (with Box-Wilson optimization) method [169].

The tensile-shear tests were performed with an MTS 810 universal material testing machine according to AWS D8.1M standard [167].

\section{Results and discussion}

\subsection{Experimental STS data}

The objective of the RSW experiments was to achieve the highest STS value with an acceptable weld quality. The STS values of the optimized joints and their welding parameters are listed in Table 2. It is evident from 
Table 2 Main properties of the base materials used for own RSW experiments

\begin{tabular}{|c|c|c|c|c|c|}
\hline \multicolumn{2}{|c|}{ RSW joint } & \multirow{2}{*}{$\begin{array}{c}\text { Sheet } \\
\text { thickness } \\
(\mathrm{mm})\end{array}$} & \multirow{2}{*}{$\begin{array}{l}\text { Current } \\
(-) /(k A)\end{array}$} & \multirow{2}{*}{$\begin{array}{c}\text { Time } \\
\text { (cycles) }\end{array}$} & \multirow{2}{*}{$\begin{array}{l}\text { STS } \\
(\mathrm{kN})\end{array}$} \\
\hline Sheet 1 & Sheet 2 & & & & \\
\hline DP 800 & DP 800 & 1.2 & $60 / 8.9$ & 30 & $23.0 \pm 2.0$ \\
\hline TRIP 800 & TRIP 800 & 1.2 & $70 / 10.1$ & 50 & $16.3 \pm 1.9$ \\
\hline **TRIP 800 & TRIP 800 & 1.2 & $50 / 7.7$ & 35 & $11.8 \pm 0.9$ \\
\hline DP 800 & TRIP 800 & 1.2 & $45 / 7.1$ & 45 & $17.3 \pm 0.7$ \\
\hline CP 1000 & CP 1000 & 1.4 & $47 / 7.4$ & 32 & $20.3 \pm 1.2$ \\
\hline DP 1000 & DP 1000 & 1 & $45 / 7.1$ & 20 & $13.7 \pm 0.8$ \\
\hline $1400 \mathrm{M}$ & $1700 \mathrm{M}$ & 1 & $42 / 6.8$ & 28 & $16.0 \pm 1.0$ \\
\hline $1400 \mathrm{M}$ & Hardox 450 & 1 & $42 / 6.8$ & 23 & $15.7 \pm 0.7$ \\
\hline *1500 M & $1500 \mathrm{M}$ & 1 & $35 / 5.9$ & 20 & $14.9 \pm 0.9$ \\
\hline *1500 M & Hardox450 & 1 & $50 / 7.7$ & 30 & $16.4 \pm 1.7$ \\
\hline *1700 M & $1700 \mathrm{M}$ & 1 & $46 / 7.3$ & 14 & $17.7 \pm 0.6$ \\
\hline *1700 M & S 1300 & 1 & $42 / 6.8$ & 21 & $13.9 \pm 0.8$ \\
\hline *Hardox450 & Hardox450 & 1 & $50 / 7.7$ & 30 & $22.0 \pm 2.2$ \\
\hline **Hardox450 & Hardox 450 & 1 & $50 / 7.7$ & 20 & $20.1 \pm 4.4$ \\
\hline
\end{tabular}

* Previously published here [22]; ** Different optimization method [67]

the table that the higher strength steels need to be welded with a shorter work schedule and higher current values. Moreover, the possible STS values are increasing with the base materials thickness.

All joints were defect-free and had the favorable pullout type fracture during tensile-shear testing.

It must be emphasized that the optimization for the highest STS was made within the boundaries of the RSW machine used in the experimental tests. Higher STS values could be achieved by: (a) using flat tip electrodes (other machine arm assembly required), (b) higher electrode force, (c) MFDC machine, (d) complex work schedule. This means the measured STS values are little less than the than the maximal achievable values for a given steel sheet. Which is not a big problem, because little underestimation of the highest achievable STS means staying on the safe side for the joint design for shear loading.

\subsection{Evaluation of the STS data according to the literature models}

The experimental STS data and those obtained from the literature are investigated here. Altogether those STS values are examined based on the different STS prediction models. On Figs. 4 and 5, the actual measured STS values are divided by the corresponding values obtained from the various models. Note: for dissimilar welds the calculations were done for the weaker side (according to th investigated formula) of the joint.
Dividing the actual values by the ISO (Eq. (3)) and the Radakovic and Tumuluru equations (Eq. (4)), a clear decreasing trend can be observed (Fig. 4(a) and (b), respectively) for similar and dissimilar welds in the whole tensile strength region.

The ratio of the measured and predicted STS values can be handled as a kind of safety factor (if greater than 1); therefore, it would be better if the ratio of the measured and predicted values would not change with the base materials $R_{m}$ range.

In Fig. 4(a), this ratio for $d_{w}=3.5 \cdot \sqrt{t}$ is decreasing from $\sim 2.5$ till 1 at $R_{m}=1600 \mathrm{MPa}$, at higher $R_{m}$ this model overestimates the actual STS of the welds. For a larger weld nugget this ratio decreases from $\sim 2$ to 1 till $R_{m}=1200 \mathrm{MPa}$.
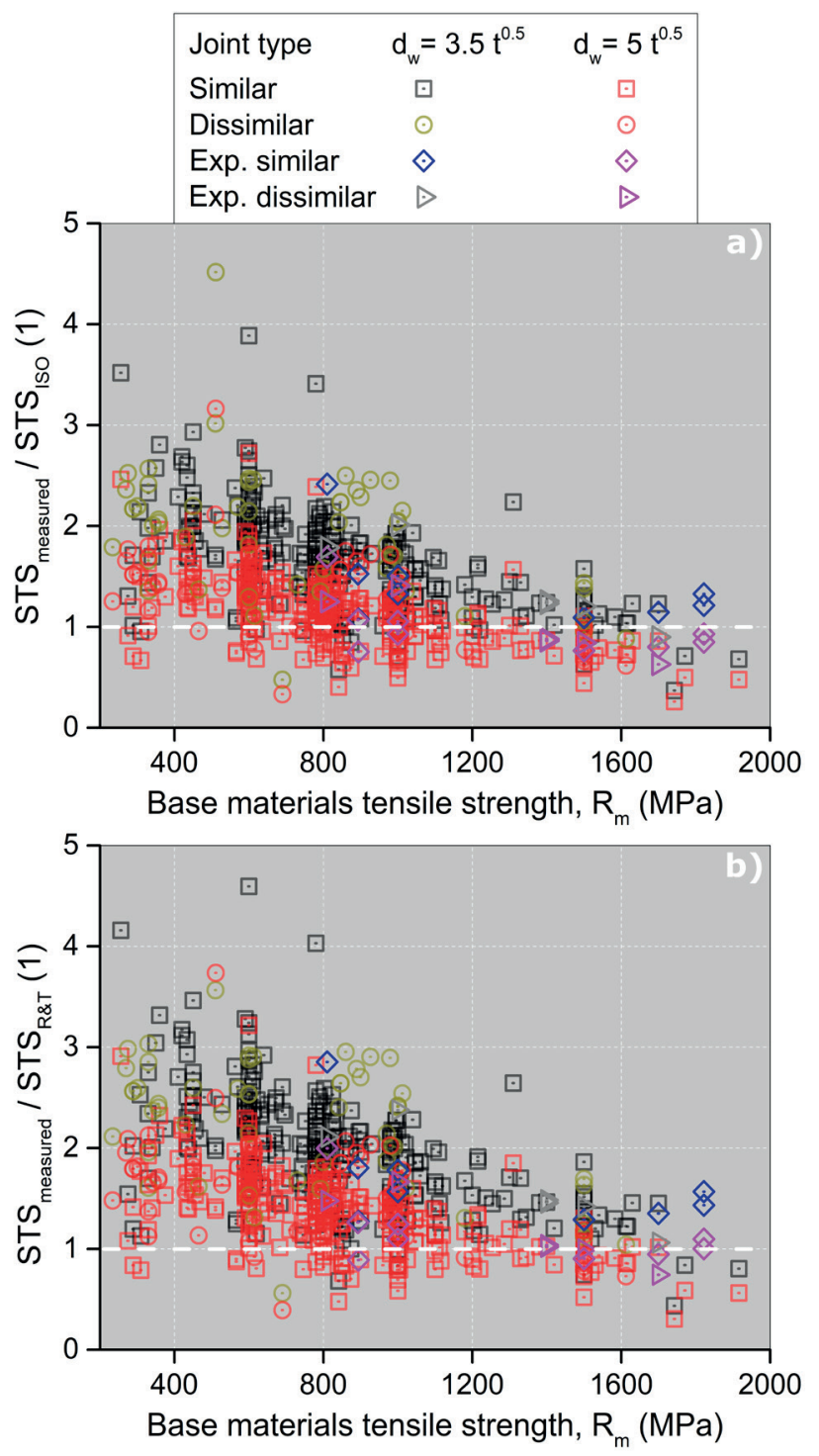

Fig. 4 Measured STS values from the literature and the experimental (Exp.) data divided by the different STS functions (Eqs. (3) and (4)) for two different weld nugget sizes $\left(d_{w}=3.5 \cdot \sqrt{t}\right.$ and $\left.d_{w}=5 \cdot \sqrt{t}\right)$ 


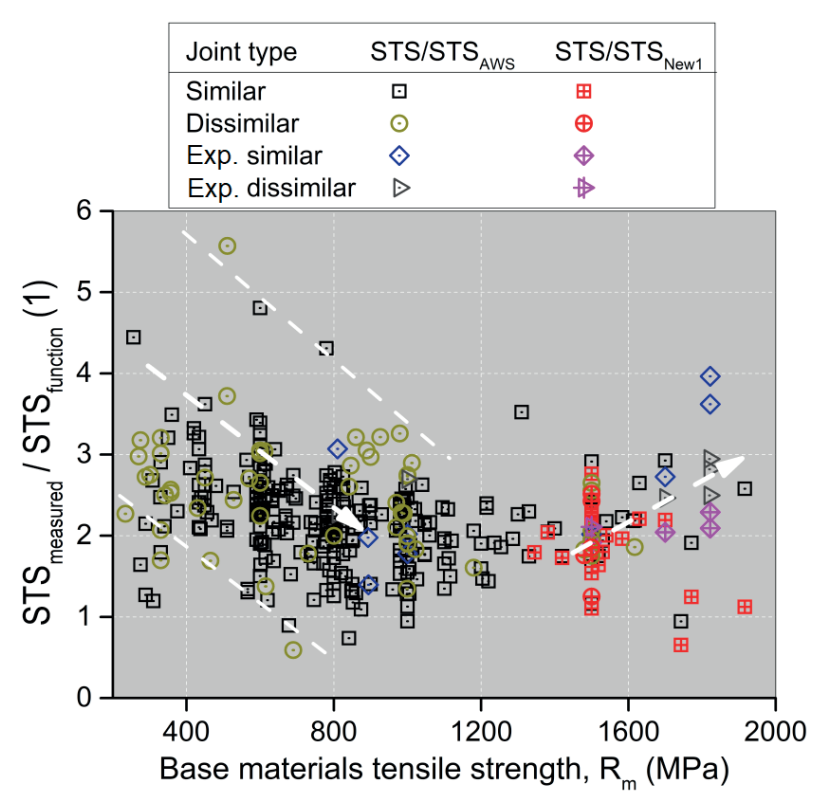

Fig. 5 Measured STS values from the literature and the experimental (Exp.) work divided by the different STS functions (Eqs. (1) and (2))

In Fig. 4(b), the measured values being divided by the Radakovic and Tumuluru equation, which has the same characteristic as the ISO equation, showing very similar plots, only the transition of this quotient from $>1$ to $<1$ occurs at different base materials $R_{m}$. This ratio for $d_{w}=3.5 \cdot \sqrt{t}$ begins with $\sim 3$ to decrease till 1 at base materials $R_{m}=1600 \mathrm{MPa}$, for $d_{w}=5 \cdot \sqrt{t}$ from $\sim 2$ to 1 at $R_{m}=1400 \mathrm{MPa}$.

In Fig. 5, the values are divided by the AWS function (Eq. (1)) and at base materials $R_{m}>1340 \mathrm{MPa}$ by the previous correlation proposed by the authors (Eq. (2)). This plot can be divided into two characteristic parts. Until $R_{m} \sim 1200 \mathrm{MPa}$, the $\mathrm{STS}_{\text {measured }} / \mathrm{STS}_{\mathrm{AWS}}$ values continuously decrease from $\sim 4$ to $\sim 2$, this ratio increases at higher base materials $R_{m}$ (on Fig. 5 indicated by white arrow at $R_{m}>1340 \mathrm{MPa}$ ). This means the measured values are lot higher than the predicted ones. It is not very beneficial for the designers, because designing according the STS $_{\text {AWs }}$ function means that they have to plan with more weld nuggets than necessary. For thath reason was Eq. (2) proposed previously [22]. In Fig. 5 it is evident that the increasing part of the ratio ceased with the application of Eq. (2) and stabilized around the ratio of 1-3.

\subsection{Determination of a new STS prediction model}

To have a more constant STS measured $_{\text {STS }}$ predicted $_{\text {ratio a new }}$ function has been determined based on experimental data and the STS data of about 150 papers [12, 17, 22-165]. All the STS data is represented in Fig. 6 as a 3D plot.
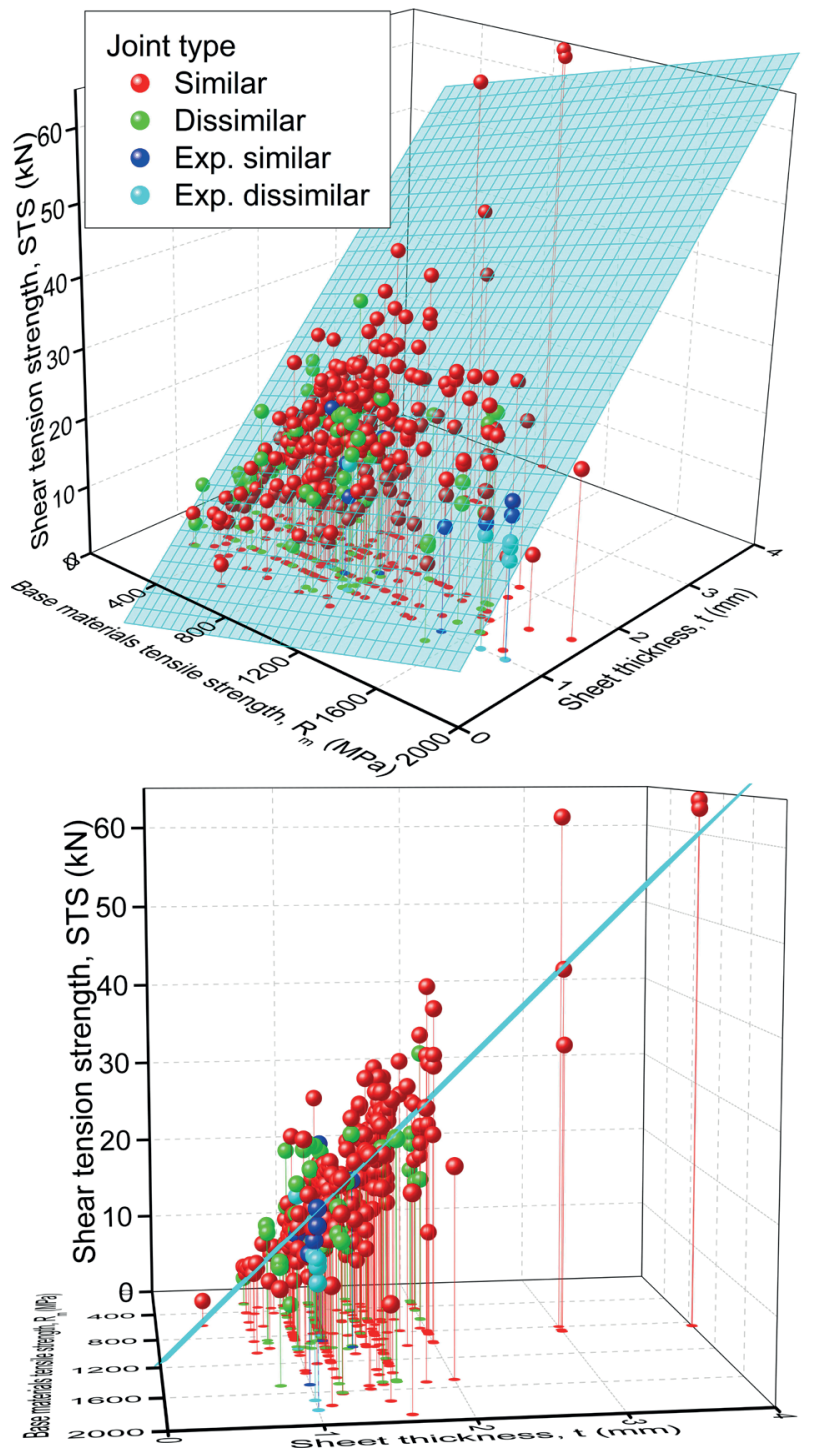

Fig. 6 Measured STS values from the literature and experimental (Exp.) work and a fitted plane (Eq. (8))

Several types of linear and nonlinear surfaces have been fitted on the STS values. There is no significant difference between them for the current available information; therefore also for easier handling, a 3D plane function has been determined $\left(\mathrm{STS}_{\mathrm{New} 2}\right)$ (Eq. (8)).

$S T S_{\text {New } 2}=-10.10+0.0088 \cdot R_{m}+15.80 \cdot t(k N)$

In this formual $R_{m}$ is the tensile strength of the steel in $\mathrm{MPa}$ and $t$ the sheet thickness in mm.

For comparison the different STS models are plotted for $1 \mathrm{~mm}$ sheet thickness in Fig. 7. In this case, the $\mathrm{STS}_{\mathrm{New} 2}$ function predicts a higher STS value than the other equations, while at $R_{m} \sim 1345 \mathrm{MPa}$ it predicts lower strength than the $\mathrm{STS}_{\mathrm{ISO}}$ function for $d_{w}=5 \cdot \sqrt{t}$. For larger sheet thicknesses, this transition shifts for the smaller base materials 


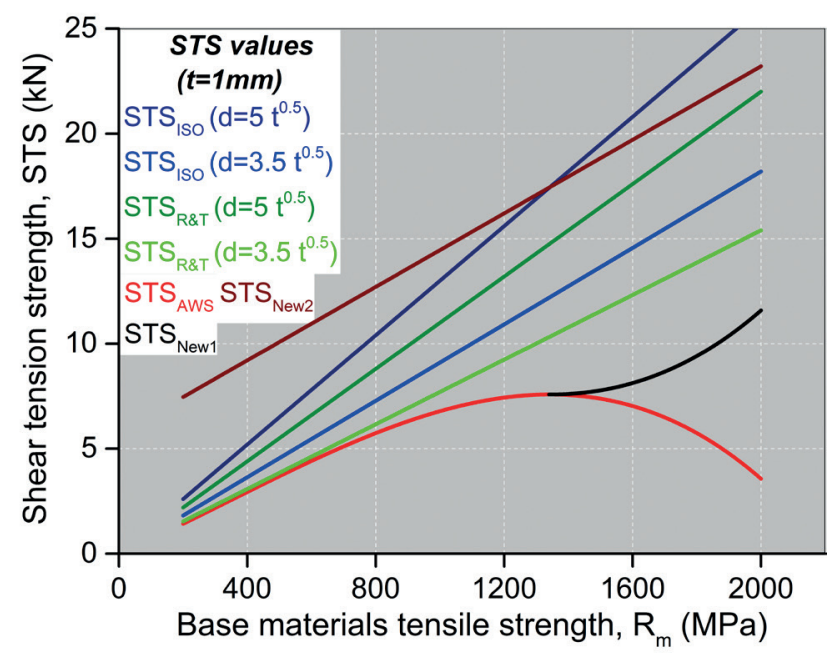

Fig. 7 Graphical representation of the different STS models (Eqs. (1)-(4) and 8) for $t=1 \mathrm{~mm}$ sheet thickness

strength, e.g., for $2 \mathrm{~mm}$ sheet thickness the transition occurs at $R_{m} \sim 750 \mathrm{MPa}$, while at $R_{m} \sim 1600 \mathrm{MPa}$ the predicted $\mathrm{STS}_{\mathrm{New} 2}$ value is smaller than the $\mathrm{STS}_{\mathrm{R} \& \mathrm{~T}}$ value for $d_{w}=5$. $\sqrt{t}$. So it seems Eq. (8) approximates better the measured STS values for the whole high strength base materials $400 \mathrm{MPa}<R_{m} \sim<2000 \mathrm{MPa}$ range for thin sheets.

\subsection{Evaluation of the STS data according to the different models for selected HSS and UHSS types}

The different STS prediction models were investigated especially for HSS ans UHSS steel grades. The most literature data was available for the DP, TRIP and martensitic steel grades in this strength regions. The measured STS values of these three grades (in similar joints) are divided by the different STS prediction functions are shown in Fig. 8.

DP steel grades are in the $400 \mathrm{MPa}<R_{m}<1300 \mathrm{MPa}$ range (Fig. 8(a)). The $\mathrm{STS}_{\text {measured }} / \mathrm{STS}_{\text {function }}$ values for the AWS model continuously decrease from approx. 2.5-3.5 range to $1-1.5$ range with the higher $R_{m}$. In case of the ISO function (for $d_{w}=5 \cdot \sqrt{t}$ ) this decreasing trend can still be observed, but at a smaller extent from approx. 2-1.5 range to $0.5-1.5$ range. The values computed with the New 2 function (Eq. (8)) scatter in the whole $R_{m}$ range, homogeneously in the $0.5-1.5$ range.

TRIP steel grades are in the $500 \mathrm{MPa}<R_{m}<1300 \mathrm{MPa}$ range (Fig. 8(b)). The $\mathrm{STS}_{\text {measured }} / \mathrm{STS}_{\text {function }}$ values for the AWS model are approx. $15-2.5$ in the whole tensile strength range. In case of the ISO function (for $d_{w}=5 \cdot \sqrt{t}$ ) this range is significantly narrower approx. 0.5-1.5. In the New 2 function (Eq. (8)), this range is slightly smaller approx. 0.4-1.4, and even smaller for $R_{m}<700 \mathrm{MPa}$.


Fig. 8 Measured STS values from the literature and experimental work divided with the different STS functions (Eqs. (1)-(3) and Eq. (8)) in similar joints for: DP steels a), TRIP steels b) and martensitic steels c)

Martensitic steel grades are in the $700 \mathrm{MPa}<R_{m}<$ $1900 \mathrm{MPa}$ range (Fig. 8(c)). The $\mathrm{STS}_{\text {measured }} / \mathrm{STS}_{\text {function }}$ values for the AWS model are continuously decreasing from approx. 2.1-2.8 range to $1.8-2.5$ range at the higher $R_{m}$. 
Above $R_{m}=1340 \mathrm{MPa}$, this ratio starts to increase again till $\sim 2.6-3$ range. These values for the New1 function (Eq. (2)) do not increase but are in the approx. 1.3-2.5 range. In the case of the ISO function (for $d_{w}=5 \cdot \sqrt{t}$ ), this range is significantly narrower but the $\mathrm{STS}$ measured $/ \mathrm{STS}_{\text {function }}$ values are continuously decreasing from the approx. $1-1.5$ range to the 0.5-0.9 range at higher $R_{m}$. This means that this formula first underestimates the real STS values, than from approx. $R_{m}>1200 \mathrm{MPa}$ it overestimates them.

In case of the New 2 function (Eq. (8)), $\mathrm{STS}_{\text {measured }} / \mathrm{STS}_{\text {function }}$ range is smaller approx. $0.4-0.6$ and the values are more homogeneously distributed in the whole $R_{m}$ range.

In Fig. 9 the measured STS values from the literature and from the experimental work are divided by the devel-

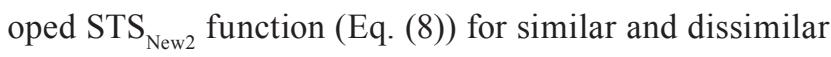
joints. As it can be seen, the values scatter around 1, a fitted line with fixed intercept at 1 had a minimal slope of $3 \times 10^{-5} \mathrm{MPa}^{-1}$, with the $\mathrm{R}^{2}$ of 0.9 .

Therefore it can be concluded, that the new function approximates better the measured STS values in the whole $R_{m}$ range for similar and dissimilar joints than the existing literature and standards equations. Moreover, the equation has the advantage to be only dependent on the base materials tensile strength and the sheet thickness, and not on the weld nugget size.

\section{Conclusions}

In this current research, a large amount of literature and experimental data have been investigated to better predict the shear tension strength (STS) of resistance spot welded high and ultra-high strength thin steel sheets. From the available data, the following conclusions can be drawn:

- The standardized AWS D8.1M function underestimates the measured STS values, and the ratio of $\mathrm{STS}_{\text {measured }} / \mathrm{STS}_{\mathrm{AWS}}$ decreases with the material tensile strength, and due to the nature of this function it starts do increase again above $1340 \mathrm{MPa}$.

- The standardized ISO 14373:2015(en) [168] and the Radakovic D. and Tumuluru M. functions underestimate the measured STS values at lower base materials tensile strength, and the ratio of $\mathrm{STS}_{\text {measured }} / \mathrm{STS}_{\text {function }}$ decreases with the material tensile strength. At certain tensile strength (depending on the function and the required weld nugget size), this ratio is below 1 meaning that the functions start to overestimate the STS values.

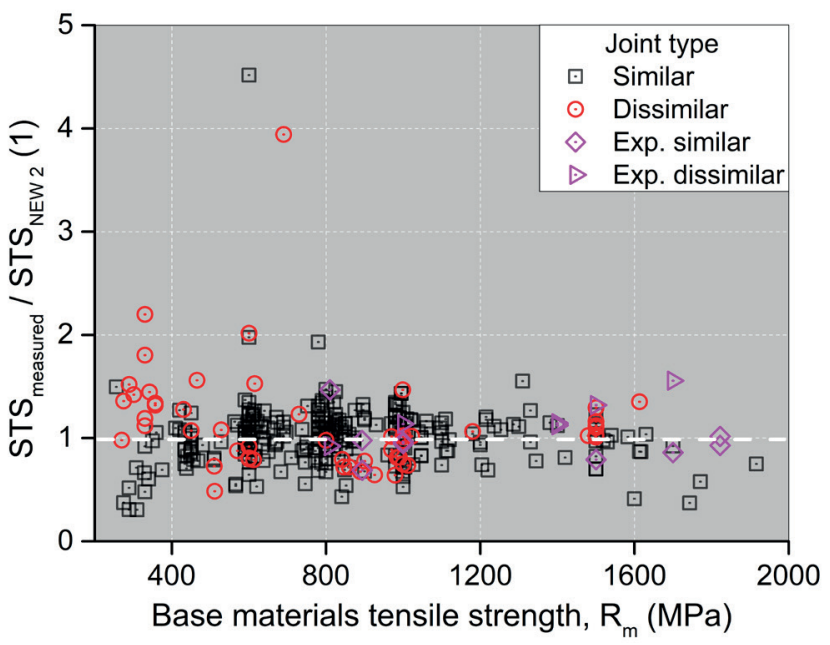

Fig. 9 Measured STS values from the literature and experimental (Exp.) work divided by the developed new function (Eq. (8)) for similar and dissimilar joints

- A new formula has been proposed (Eq. (8)), which gives a homogeneous $\mathrm{STS}_{\text {measured }} / \mathrm{STS}_{\text {function }}$ ratio (0.5-1.5 range) over the 400-1900 MPa base material tensile strength range. It also gives a narrower range of $\mathrm{STS}_{\text {measured }} / \mathrm{STS}_{\text {function }}$ values at any selected base materials strength. It also works better for DP, TRIP and martensitic steels. This formula is dependent on the base materials tensile strength and the sheet thickness, and not on the weld nugget size.

- The proposed new function can be a loocrative tool for the designers in the planning stage of resistance spot welded components made of thin sheets (approx. $<3 \mathrm{~mm}$ ) under tensile-shear load.

\section{Acknowledgements}

The research reported in this paper and carried out at BME has been supported by the NRDI Fund (TKP2020 IES, Grant No. BME-IE-NAT) based on the charter of bolster issued by the NRDI Office under the auspices of the Ministry for Innovation and Technology.

The research reported in this paper and carried out at BME has been supported by the NRDI Fund (TKP2020 NC, Grant No. BME-NC) based on the charter of bolster issued by the NRDI Office under the auspices of the Ministry for Innovation and Technology.

Parts of this paper have been supported by the National Research, Development and Innovation Office - NKFIH, OTKA PD 138729. 


\section{References}

[1] Gyura, L., Gáspár, M., Balogh, A. "Investigation of Thermal Effects of Flame Straightening on High-Strength Steels", In: Jármai, K., Voith, K. (eds.) Vehicle and Automotive Engineering 3. Lecture Note on Mechanical Engineering, Springer, Singapore, 2021, pp. 526-538.

https://doi.org/10.1007/978-981-15-9529-5_46

[2] Sisodia, R. P. S., Gáspár, M., Sepsi, M., Mertinger, V. "Comparative evaluation of residual stresses in vacuum electron beam welded high strength steel S960QL and S960M butt joints", Vacuum, 184, Article No. 109931, 2021.

https://doi.org/10.1016/j.vacuum.2020.109931

[3] Lukács, J., Mobark, H. F. H., Dobosy, Á. "High Cycle Fatigue Resistance of $700 \mathrm{MPa}$ and $960 \mathrm{MPa}$ Strength Categories High Strength Steels and Their Gas Metal Arc Welded Joints", In: Jármai, K., Voight, K. (eds.) Vehicle and Automotive Engineering 3. Lecture Notes in Mechanical Engineering, Springer, Singapore, 2021, pp. 539-555.

https://doi.org/10.1007/978-981-15-9529-5 47

[4] Bitay, E., Bagyinszki, G. "Jármüipari acélok szilárdságnövelési lehetőségei" (Opportunities of strenght-increasing of automotive steels), Műszaki Tudományos Közlemények, 3, pp. 91-94, 2015. (in Hungarian) https://doi.org/10.33895/mtk-2015.03.15

[5] Orosz, Cs., Palotás, B., Dobránszky, J. "Welding Investigations of Modern High Strength Dual Phase and TRIP-Steel for Automotive Industry Application", Materials Science Forum, 537-538, pp. 431-438, 2007.

https://doi.org/10.4028/www.scientific.net/MSF.537-538.431

[6] Valaee-Tale, M., Sheikhi, M., Mazaheri, Y., Malek Ghaini, F., Usefifar, G. R. "Criterion for predicting expulsion in resistance spot welding of steel sheets", Journal of Materials Processing Technology, 275, Article No. 116329, 2020.

https://doi.org/10.1016/j.jmatprotec.2019.116329

[7] Borhy, I., Kovács, L. "A Lightweight Design Approach for Welded Railway Vehicle Structures of Modern Passenger Coach", In: Jármai, K., Bolló, B. (eds.) Vehicle and Automotive Engineering, Lecture Notes in Mechanical Engineering, Springer, Cham, Switzerland, 2017, pp. 425-437. https://doi.org/10.1007/978-3-319-51189-4_37

[8] Pogonyi, T., Palotás, B., Bakos, L. "Arc Welding of Zinc Coated High Strength Steels", In: Jármai, K., Bolló, B. (eds.) Vehicle and Automotive Engineering 2., Lecture Notes in Mechanical Engineering, Springer, Cham, Switzerland, 2018, pp. 768-778. https://doi.org/10.1007/978-3-319-75677-6_65

[9] Godzsák, M., Lévai, G., Vad, K., Csik, A., Hakl, J., Kulcsár, T., Kaptay, G. "Coloring hot-dip galvanization of steel samples in industrial zinc-manganese baths", Journal of Mining and Metallurgy, Section B: Metallurgy, 53(3), pp. 319-326, 2017. https://doi.org/10.2298/JMMB170531028G

[10] Tomków, J., Fydrych, D., Rogalski, G. "Dissimilar underwater wet welding of HSLA steels", The International Journal of Advanced Manufacturing Technology, 109(3-4), pp. 717-725, 2020. https://doi.org/10.1007/s00170-020-05617-y
[11] de la Garza, M., del C. Zambrano, P., Guerrero-Mata, M. P., Réti, T., Réger, M., Felde, I., Colás, R. "Diffusion in Electrodes Used for Resistance Spot Welding of Galvannealed Steel", Defect and Diffusion Forum, 297-301, pp. 300-307, 2010.

https://doi.org/10.4028/www.scientific.net/DDF.297-301.300

[12] Russo Spena, P., De Maddis, M., Lombardi, F., Rossini, M. "Dissimilar Resistance Spot Welding of Q\&P and TWIP Steel Sheets", Materials and Manufacturing Processes, 31(3), pp. 291299, 2016.

https://doi.org/10.1080/10426914.2015.1048476

[13] Bézi, Z., Baptiszta, B., Szávai, S. "Experimental and numerical analysis of resistance spot welded joints on DP600 sheets", Welding \& Material Testing, 23(4), pp. 7-12, 2014.

[14] Pellegrinelli, S., Pedrocchi, N., Tosatti, L. M., Fischer, A., Tolio, T. "Multi-robot spot-welding cells for car-body assembly: Design and motion planning", Robotics and Computer-Integrated Manufacturing, 44, pp. 97-116, 2017.

https://doi.org/10.1016/j.rcim.2016.08.006

[15] Kim, J. W., Murugan, S. P., Yoo, J.-H., Ashiri, R., Park, Y.-D. "Enhancing nugget size and weldable current range of ultra-highstrength steel using multi-pulse resistance spot welding", Science and Technology of Welding and Joining, 25(3), pp. 235-242, 2020. https://doi.org/10.1080/13621718.2019.1680483

[16] Wintjes, E., DiGiovanni, C., He, L., Bag, S., Goodwin, F., Biro, E., Zhou, Y. "Effect of Multiple Pulse Resistance Spot Welding Schedules on Liquid Metal Embrittlement Severity", Journal of Manufacturing Science and Engineering, 141(10), Article No. 101001, 2019

https://doi.org/10.1115/1.4044099

[17] Liu, X. D., Xu, Y. B., Misra, R. D. K., Peng, F., Wang, Y., Du, Y. B. "Mechanical properties in double pulse resistance spot welding of Q\&P 980 steel", Journal of Materials Processing Technology, 263, pp. 186-197, 2019. https://doi.org/10.1016/j.jmatprotec.2018.08.018

[18] Stadler, M., Schnitzer, R., Gruber, M., Steineder, K., Hofer, C. "Influence of the Cooling Time on the Microstructural Evolution and Mechanical Performance of a Double Pulse Resistance Spot Welded Medium-Mn Steel", Metals, 11(2), Article No. 270, 2021. https://doi.org/10.3390/met11020270

[19] Soomro, I. A., Pedapati, S. R., Awang, M. "Double Pulse Resistance Spot Welding of Dual Phase Steel: Parametric Study on Microstructure, Failure Mode and Low Dynamic Tensile Shear Properties", Materials, 14(4), Article No. 802, 2021. https://doi.org/10.3390/ma14040802

[20] Tutar, M., Aydın, H., Bayram, A. "The Optimisation of Welding Parameters for Electrical Resistance Spot-Welded TWIP Steels Using a Taguchi Method", Pamukkale University Journal of Engineering Sciences, 24(4), pp. 650-657, 2018. https://doi.org/10.5505/pajes.2018.88965

[21] Rao, S. S., Arora, K. S., Sharma, L., Chhibber, R. "Investigations on Mechanical Behaviour and Failure Mechanism of Resistance SpotWelded DP590 Steel Using Artificial Neural Network", Transactions of the Indian Institute of Metals, 74(6), pp. 1419-1438, 2021. https://doi.org/10.1007/s12666-021-02237-2 
[22] Varbai, B., Sommer, C., Szabó, M., Tóth, T., Májlinger, K. "Shear tension strength of resistant spot welded ultra high strength steels", Thin-Walled Structures, 142, pp. 64-73, 2019. https://doi.org/10.1016/j.tws.2019.04.051

[23] Chung, K., Noh, W., Yang, X., Han, H. N., Lee, M.-G. "Practical failure analysis of resistance spot welded advanced high-strength steel sheets", International Journal of Plasticity, 94, pp. 22-147, 2017. https://doi.org/10.1016/j.ijplas.2016.10.010

[24] Long, H., Hu, Y., Jin, X., Shao, J., Zhu, H. "Effect of holding time on microstructure and mechanical properties of resistance spot welds between low carbon steel and advanced high strength steel", Computational Materials Science, 117, pp. 556-563, 2016. https://doi.org/10.1016/j.commatsci.2016.01.011

[25] Ao, S., Shan, H., Cui, X., Luo, Z., Chao, Y. J., Ma, M. "Effect of specimen width on the failure behavior in resistance spot weld tensile shear testing", Welding in the World, 60(6), pp. 1095-1107, 2016. https://oi.org/10.1007/s40194-016-0384-y

[26] Zhao, D. W., Wang, Y. X., Zhang, L., Zhang, P. "Effects of electrode force on microstructure and mechanical behavior of the resistance spot welded DP600 joint", Materials \& Design, 50, pp. 72-77, 2013.

https://doi.org/10.1016/j.matdes.2013.02.016

[27] Zhao, Y. Y., Zhang, Y. S., Wang, P.-C. "Weld Formation Characteristics in Resistance Spot Welding of Ultra-Thin Steel: High welding current and short welding time were found to produce the best combination of strength and weld size", Welding Journal, 96(2), pp. 71-82, 2017.

[28] Weber, G., Göklü, S. "Resistance Spot Welding of Uncoated and Zinc Coated Advanced High-Strength Steels (AHSS) - Weldability and Process Reliability-Influence of Welding Parameters", Welding in the World, 50(3-4), pp. 3-12, 2006. https://doi.org/10.1007/bf03263428

[29] Pal, T. K., Bhowmick, K. "Resistance Spot Welding Characteristics and High Cycle Fatigue Behavior of DP 780 Steel Sheet", Journal of Materials Engineering and Performance, 21(2), pp. 280-285, 2012.

https://doi.org/10.1007/s11665-011-9850-2

[30] Ertek Emre, H., Kaçar, R. "Resistance Spot Weldability of Galvanize Coated and Uncoated TRIP Steels", Metals, 6(12), Article No. 299, 2016. https://doi.org/10.3390/met6120299

[31] Ghassemi-Armaki, H., Bhat, S., Kelley, S., Sadagopan, S. "QuasiStatic Spot Weld Strength of Advanced High-Strength Sheet Steels", Welding Journal, 96, pp. 104-112, 2017.

[32] Sevim, I., Hayat, F., Kulekci, M. K. "Nucleus geometry and mechanical properties of resistance spot welded coated-uncoated DP automotive steels", Bulletin of Materials Science, 36(6), pp. 1049-1055, 2013. https://doi.org/10.1007/s12034-013-0559-8

[33] Wan, X., Wang, Y., Zhang, P. "Modelling the effect of welding current on resistance spot welding of DP600 steel", Journal of Materials Processing Technology, 214(11), pp. 2723-2729, 2014. https://doi.org/10.1016/j.jmatprotec.2014.06.009
[34] Bouzekri, M., Dancette, S., Dupuy, T., Lens, A., Nait Oultit, B., Massardier, V., FabrÈgue, D., Klocker, H. "An Investigation of Failure Types in High-Strength Steel Resistance Spot Welds", Welding in the World, 54(3), pp. 3-14, 2010. https://doi.org/10.1007/bf03263485

[35] Liang, X., Yuan, X., Wang, H., Li, X., Li, C., Pan, X. "Microstructure, mechanical properties and failure mechanisms of resistance spot welding joints between ultra high strength steel $22 \mathrm{MnB} 5$ and galvanized steel HSLA350", International Journal of Precision Engineering and Manufacturing, 17(12), pp. 1659-1664, 2016. https://oi.org/10.1007/s12541-016-0192-8

[36] Liu, W., Wang, R., Han, J., Xu, X., Li, Q. "Microstructure and mechanical performance of resistance spot-welded cold-rolled high strength austenitic stainless steel", Journal of Materials Processing Technology, 210(14), pp. 1956-1961, 2010. https://doi.org/10.1016/j.jmatprotec.2010.07.008

[37] Daneshpour, S., Koçak, M., Riekehr, S., Gerritsen, C. H. J. "Mechanical Characterization and Fatigue Performance of Laser and Resistance Spot Welds", Welding in the World, 53(9), pp. R221-R228, 2009. https://doi.org/10.1007/bf03321133

[38] Oikawa, H., Murayama, G., Hiwatashi, S., Matsuyama, K. "Resistance Spot Weldability of High Strength Steel Sheets for Automobiles and the Quality Assurance of Joints", Welding in the World, 51(3), pp. 7-18, 2007.

https://doi.org/10.1007/bf03266555

[39] Brauser, S., Pepke, L.-A., Weber, G., Rethmeier, M. "Influence of Production-Related Gaps on Strength Properties and Deformation Behaviour of Spot Welded Trip Steel HCT690T", Welding in the World, 56(3), pp. 115-125, 2012.

https://doi.org/10.1007/bf03321342

[40] Pouranvari, M., Marashi, S. P. H. "Failure mode transition in AHSS resistance spot welds. Part I. Controlling factors", Materials Science and Engineering: A, 528(29-30), pp. 8337-8343, 2011. https://doi.org/10.1016/j.msea.2011.08.017

[41] Rossillon, F., Galtier, A., Robert, J. L., Duchet, M., Lens, A., Oikawa, H. "Effect of Welding Cycle on the Fatigue Behaviour of Resistance Spot Welded Dual Phase Steels", Welding in the World, 52(11), pp. 30-41, 2008. https://doi.org/10.1007/bf03266680

[42] Tolf, E., Hedegård, J. "Influence of Reduced Cooling Time on the Properties of Resistance Spot Welds", Welding in the World, 52(3), pp. 43-53, 2008. https://doi.org/10.1007/bf03266631

[43] Den Uijl, N., Moolevliet, T., Mennes, A., Van Der Ellen, A. A., Smith, S., Van Der Veldt, T.,..., Fukui, K. "Performance of Resistance Spot-Welded Joints in Advanced High-Strength Steel in Static and Dynamic Tensile Tests", Welding in the World, 56(7), pp. 51-63, 2012. https://doi.org/10.1007/bf03321365

[44] Den Uijl, N., Azakane, F., Kilic, S., Docter, V. "Performance of Tensile Tested Resistance Spot and Laser Welded Joints at Various Angles", Welding in the World, 56(11), pp. 143-152, 2012. https://doi.org/10.1007/bf03321404 
[45] Yu, J., Shim, J., Rhee, S. "Characteristics of Resistance Spot Welding for $1 \mathrm{GPa}$ Grade Twin Induced Plasticity Steel", Materials Transactions, 53(11), pp. 2011-2018, 2012.

https://doi.org/10.2320/matertrans.M2012167

[46] Abadi, M. M. H., Pouranvari, M. "Failure-mode transition in resistance spot welded DP780 advanced high-strength steel: Effect of loading conditions", Materiali in tehnologije / Materials and technology 48(1), pp. 67-71, 2014.

[47] Eva, S., Bohumil, C., Petr, H. "Dynamic Fracture Behavior of the Martensitic High Strength Steel after Spot Welding", Materials Today: Proceedings, 3(4), pp. 1156-1160, 2016. https://doi.org/10.1016/j.matpr.2016.03.014

[48] Khan, M. I., Kuntz, M. L., Biro, E., Zhou, Y. "Microstructure and Mechanical Properties of Resistance Spot Welded Advanced High Strength Steels", Materials Transactions, 49(7), pp. 1629-1637, 2008. https://doi.org/10.2320/matertrans.MRA2008031

[49] Wei, S. T., Lv, D., Liu, R. D., Lin, L., Xu, R. J., Guo, J. Y., Wang, K. Q. "Similar and dissimilar resistance spot welding of advanced high strength steels: welding and heat treatment procedures, structure and mechanical properties", Science and Technology of Welding and Joining, 19(5), pp. 427-435, 2014. https://doi.org/10.1179/1362171814y.0000000211

[50] Tamizi, M., Pouranvari, M., Movahedi, M. "Welding metallurgy of martensitic advanced high strength steels during resistance spot welding", Science and Technology of Welding and Joining, 22(4), pp. 327-335, 2017.

https://doi.org/10.1080/13621718.2016.1240979

[51] Bohr, J. "A Comparative Study of Joint Efficiency for AHSS", [pdf], Auto/Steel Partnership, Availabe at: http://www.autosteel.org/ $\sim /$ media/Files/Autosteel/Great\%20Designs\%20in\%20Steel/ GDIS\%202009/11\%20-\%20A\%20Comparative\%20Study\%20of\% 20Joint $\% 20$ Efficiency\%20forAHSS.pdf [Accessed: 10 May 2017]

[52] Kazdal Zeytin, H., Ertek Emre, H., Kaçar, R. "Properties of Resistance Spot-Welded TWIP Steels", Metals, 7(1), Article No. 14, 2017. https://doi.org/10.3390/met7010014

[53] Prém, L., Balogh, A., Bézi, Z. "A kísérletes technológiafejlesztés hatékonyságának javítása végeselemes modellezés alkalmazásával nagyszilárdságú DP acélok ponthegesztésekor" (Improvement in effectiveness of experimental technology development by finite element modelling for resistance spot welding od high strength DP steels), 8. Nemzetközi Hegesztési Konferencia, Dunaújvárosi Egyetem, Dunaújváros, Hungary, 2016. (in Hungarian)

[54] Prém, L., Balogh, A. "A szakaszos energiabevitelben rejlö lehetőségek kiaknázása nagyszilárdságú, ferrit-martensites duplex szövetủ autóipari acélok ellenállás-ponthegesztésekor" (Exploiting the potential of discontinous energy input in resistance spot welding of high-strength ferrit-martensitic automotive steels), Hegesztéstechnika, 26(3), pp. 47-56, 2015. (in Hungarian)

[55] Russo Spena, P., De Maddis, M., Lombardi, F., Rossini, M. "Investigation on Resistance Spot Welding of TWIP Steel Sheets", steel research international, 86(12), pp. 1480-1489, 2015. https://doi.org/10.1002/srin.201400336
[56] Prém, L., Bézi, Z., Balogh, A. "Development of Complex Spot Welding Technologies for Automotive DP Steels with FEM Support", In: Jármai, K., Bolló, B. (eds.), Vehicle and Automotive Engineering: Lecture Notes in Mechanical Engineering, Springer International Publishing, Cham, Switzerland, 2017, pp. 407-423. https://doi.org/10.1007/978-3-319-51189-4_36

[57] Tolf, E. "Challenges in Resistance Welding of Ultra High Strength Steels", Licentiate Thesis, KTH Royal Institute of Technology, 2015.

[58] Sperle, J. O., Olsson, K. "High-strength automotive sheet steels for weight reduction and safety applications", In: Proceedings of the Symposium on High-Strength Sheet Steels for the Automotive Industry, The Society, 1994, pp. 65-77.

[59] Radakovic, D., Tumuluru, M. "Predicting Resistance Spot Weld Failure Modes in Shear Tension Tests of Advanced High-Strength Automotive Steels", Welding Journal, 87, pp. 96-106, 2008.

[60] Marashi, P., Pouranvari, M., Sanaee, S. M. H., Abedi, A., Abootalebi, S. H., Goodarzi, M. "Relationship between failure behaviour and weld fusion zone attributes of austenitic stainless steel resistance spot welds", Materials Science and Technology, 24(12), pp. 1506-1512, 2008.

https://doi.org/10.1179/174328408×262418

[61] Yi, H. L., Lee, K. Y., Lim, J. H., Bhadeshia, H. K. D. H. "Spot weldability of $\delta$-TRIP steel containing $0.4 \mathrm{wt}-\% \mathrm{C} "$, Science and Technology of Welding and Joining, 15(7), pp. 619-624, 2010. https://doi.org/10.1179/136217110x12813393169778

[62] Hayriye, E. E., Ramazan, K. "Effect of Button Geometry on TRIP800 Steel Resistance Spot Weldment", International Journal of Innovative Research in Science, Engineering and Technology, 5(12), pp. 164-171, 2016.

[63] Pouranvari, M., Mousavizadeh, S. M. "Failure mode of M130 martensitic steel resistance-spot welds", Materiali in Tehnologije/ Materials and technology, 47(6), pp. 771-776, 2013.

[64] Dancette, S., Massardier-Jourdan, V., Merlin, J., Fabrégue, D., Dupuy, T. "Investigations on the mechanical behavior of Advanced High Strength Steels resistance spot welds in Cross Tension and Tensile Shear", Advanced Materials Research, 89-91, pp. 130-135, 2010.

https://doi.org/10.4028/www.scientific.net/AMR.89-91.130

[65] Khan, M. I. "Spot Welding of Advanced High Strength Steels", MSc Thesis, University of Waterloo, 2007.

[66] Marya, M., Gayden, X. Q. "Development of Requirements for Resistance Spot Welding Dual-Phase (DP600) Steels Part 1 - The Causes of Interfacial Fracture", Welding Journal, 84(11), pp. 172182, 2005.

[67] Kiss, L., Májlinger, K., Varbai, B. "Nagyszilárdságú acéllemezek ellenállás-ponthegesztett kötéseinek optimalizálása" (Optimization of the resistance spot welded joints of high strength steel sheets), In: XXV. Nemzetközi Gépészeti Találkozó, Erdélyi Magyar Műszaki Tudományos Társaság (EMT), Cluj-Napoca, Romania, 2017, pp. 219-222. (in Hungarian)

[68] Vajdics, D., Kovács-Coskun, T. "A TRIP acél ponthegesztésének hatása" (Resistance spot welding effect in case of trip steel), XV. Müszaki Tudományos Ülésszak, Erdélyi Múzeumi Egyesület (EME), Kolozsvár, 2014, pp. 227-234. (in Hungarian) 
[69] Hunt, J., Sang, Y., Jiang, C. "A/SP Joining Technology Committee: Joint Efficiency and Repair Welding Phase II: Executive Summary", Auto/Steel Partnership, Southfield, MI, USA.

[70] Kapil, A., Lee, T., Vivek, A., Bockbrader, J., Abke, T., Daehn, G. "Benchmarking strength and fatigue properties of spot impact welds", Journal of Materials Processing Technology, 255, pp. 219233, 2018.

https://doi.org/10.1016/j.jmatprotec.2017.12.012

[71] Martín, Ó., De Tiedra, P., San-Juan, M. "Combined effect of resistance spot welding and precipitation hardening on tensile shear load bearing capacity of A286 superalloy", Materials Science and Engineering: A, 688, pp. 309-314, 2017.

https://doi.org/10.1016/j.msea.2017.02.015

[72] Pouranvari, M. "Fracture toughness of martensitic stainless steel resistance spot welds", Materials Science and Engineering: A, 680, pp. $97-107,2017$.

https://doi.org/10.1016/j.msea.2016.10.088

[73] Papadimitriou, I., Efthymiadis, P., Kotadia, H. R., Sohn, I. R., Sridhar, S. "Joining TWIP to TWIP and TWIP to aluminium: A comparative study between joining processes, joint properties and mechanical performance", Journal of Manufacturing Processes, 30, pp. 195-207, 2017.

https://doi.org/10.1016/j.jmapro.2017.09.012

[74] Rao, S. S., Chhibber, R., Arora, K. S., Shome, M. "Resistance spot welding of galvannealed high strength interstitial free steel", Journal of Materials Processing Technology, 246, pp. 252-261, 2017. https://doi.org/10.1016/j.jmatprotec.2017.03.027

[75] Shirmohammadi, D., Movahedi, M., Pouranvari, M. "Resistance spot welding of martensitic stainless steel: Effect of initial base metal microstructure on weld microstructure and mechanical performance", Materials Science and Engineering: A, 703, pp. 154161, 2017. https://doi.org/10.1016/j.msea.2017.07.067

[76] Pouranvari, M., Sobhani, S., Goodarzi, F. "Resistance spot welding of MS1200 martensitic advanced high strength steel: Microstructure-properties relationship", Journal of Manufacturing Processes, 31, pp. 867-874, 2018. https://doi.org/10.1016/j.jmapro.2018.01.009

[77] Dorribo, D., Greve, L., Díez, P., Arias, I., Larráyoz-Izcara, X. "Numerical estimation of the bearing capacity of resistance spot welds in martensitic boron steels using a J-integral fracture criterion", Theoretical and Applied Fracture Mechanics, 96, pp. 497508,2018 .

https://doi.org/10.1016/j.tafmec.2018.06.006

[78] Brauser, S., Pepke, L. A., Weber, G., Rethmeier, M. "Deformation behaviour of spot-welded high strength steels for automotive applications", Materials Science and Engineering: A, 527(26), pp. 7099-7108, 2010. https://doi.org/10.1016/j.msea.2010.07.091

[79] Lin, H. J., Kim, W. J., Chang, H. S., Choi, D. Y. "Effect of profile force on toughness of resistance spot weld joints for ultra high strength steel", Welding in the World, 62(3), pp. 481-496, 2018. https://doi.org/10.1007/s40194-018-0571-0
[80] Mahmood, T. R., Doos, Q. M., Al-Mukhtar, A. M. "Failure Mechanisms and Modeling of Spot Welded Joints in Low Carbon Mild Sheets Steel and High Strength Low Alloy Steel", Procedia Structural Integrity, 9, pp. 71-85, 2018. https://doi.org/10.1016/j.prostr.2018.06.013

[81] Noh, W., Koh, Y., Chung, K., Song, J.-H., Lee, M.-G. "Influence of dynamic loading on failure behavior of spot welded automotive steel sheets", International Journal of Mechanical Sciences, 144, pp. 407-426, 2018. https://doi.org/10.1016/j.ijmecsci.2018.06.009

[82] Hsu, T.-I., Wu, L.-T., Tsai, M.-H. "Resistance and friction stir spot welding of dual-phase (DP 780) - a comparative study", The International Journal of Advanced Manufacturing Technology, 97(5), pp. 2293-2299, 2018. https://doi.org/10.1007/s00170-018-2056-0

[83] Xing, B., Xiao, Y., Qin, Q. H., Cui, H. "Quality assessment of resistance spot welding process based on dynamic resistance signal and random forest based", The International Journal of Advanced Manufacturing Technology, 94(1), pp. 327-339, 2018. https://doi.org/10.1007/s00170-017-0889-6

[84] Vajdics, D., Kovács-Coskun, T. "A TRIP acél ponthegesztésének hatása" (Resistance spot welding effect in case of TRIP steel), In: XV. Müszaki Tudományos Ülésszak, EMT, Cluj-Napoca, Romania, 2014, pp. 227-234. (in Hungarian)

[85] Zhao, D., Wang, Y., Liang, D., Zhang, P. "Modeling and process analysis of resistance spot welded DP600 joints based on regression analysis", Materials \& Design, 110, pp. 676-684, 2016. https://doi.org/10.1016/j.matdes.2016.08.038

[86] Paveebunvipak, K., Uthaisangsuk, V. "Microstructure based modeling of deformation and failure of spot-welded advanced high strength steels sheets", Materials \& Design, 160, pp. 731-751, 2018. https://doi.org/10.1016/j.matdes.2018.09.052

[87] Ashiri, R., Mostaan, H., Park, Y.-D. "A Phenomenological Study of Weld Discontinuities and Defects in Resistance Spot Welding of Advanced High Strength TRIP Steel", Metallurgical and Materials Transactions A, 49(12), pp. 6161-6172, 2018. https://doi.org/10.1007/s11661-018-4900-0

[88] Zhang, X., Yao, F., Ren, Z., Yu, H. "Effect of Welding Current on Weld Formation, Microstructure, and Mechanical Properties in Resistance Spot Welding of CR590T/340Y Galvanized Dual Phase Steel", Materials, 11(11), Article No. 2310, 2018. https://doi.org/10.3390/ma11112310

[89] Zhang, J. P., Feng, Y., Song, L. F., Wang, G. Y., Jin, Q. S. "Research on Resistance Spot Welding Property of Hot-Stamping Quenched Steel Sheets", Advanced Materials Research, 1063, pp. 120-125, 2015.

https://doi.org/10.4028/www.scientific.net/AMR.1063.120

[90] Kimoto, N., Aito, T., Kawachi, T., Hiwatashi, S. "Strengthening mechanism of weldbonded high strength steel joints", Procedia Manufacturing, 15, pp. 1399-1406, 2018. https://doi.org/10.1016/j.promfg.2018.07.342

[91] Pouranvari, M. "Understanding the factors controlling the interfacial failure strength of advanced high-strength steel resistance spot welds: hardness vs. fracture toughness", Science and Technology of Welding and Joining, 23(6), pp. 520-526, 2018. https://doi.org/10.1080/13621718.2017.1421303 
[92] Kong, J. P., Han, T. K., Chin, K. G., Park, B. G., Kang, C. Y. "Effect of boron content and welding current on the mechanical properties of electrical resistance spot welds in complex-phase steels", Materials \& Design, 54, pp. 598-609, 2014. https://doi.org/10.1016/j.matdes.2013.08.098

[93] Pouranvari, M., Asgari, H. R., Mosavizadch, S. M., Marashi, P. H., Goodarzi, M. "Effect of weld nugget size on overload failure mode of resistance spot welds", Sciemce and Technology of Welding and Joining, 12(3), pp. 217-225, 2007. https://doi.org/10.1179/174329307x164409

[94] Pouranvari, M., Marashi, S. P. H. "Key factors influencing mechanical performance of dual phase steel resistance spot welds", Science and Technology of Welding and Joining, 15(2), pp. 149$155,2010$. https://doi.org/10.1179/136217109x12590746472535

[95] Hernandez, B. V. H., Kuntz, M. L., Khan, M. I., Zhou, Y. "Influence of microstructure and weld size on the mechanical behaviour of dissimilar AHSS resistance spot welds", Science and Technology of Welding and Joining, 13(8), pp. 769-776, 2008. https://doi.org/10.1179/136217108×325470

[96] Park, S.-S., Choi, Y.-M., Nam, D.-G., Kim, Y.-S., Yu, J.-H., Park, Y.-D. "Evaluation of Resistance Spot Weld Interfacial Fractures in Tensile-Shear Tests of TRIP 1180 Steels", Journal of Welding and Joining, The Korean Welding and Joining Society, 26(6), pp. 81-91, 2008.

https://doi.org/10.5781/KWJS.2008.26.6.081

[97] Baltazar Hernandez, V.H. "Effects of Martensite Tempering on HAZ-Softening and Tensile Properties of Resistance Spot Welded Dual-Phase Steels", PhD Thesis, University of Waterloo, 2010.

[98] Zhao, Y., Zhang, Y., Lai, X. "Analysis of Fracture Modes of Resistance Spot Welded Hot-Stamped Boron Steel", Metals, 8(10), Article No. 764, 2018. https://doi.org/10.3390/met8100764

[99] Pouranvari, M., Marashi, S. P. H., Mousavizadeh, S. M. "Failure mode transition and mechanical properties of similar and dissimilar resistance spot welds of DP600 and low carbon steels", Science and Technology of Welding and Joining, 15(7), pp. 625-631, 2010. https://doi.org/10.1179/136217110x12813393169534

[100] Pouranvari, M. "Failure mode transition in similar and dissimilar resistance spot welds of HSLA and low carbon steels", Canadian Metallurgical Quarterly, 51(1), pp. 67-74, 2012. https://doi.org/10.1179/1879139511y.0000000020

[101] Noh, W. R., Koh, Y. W., Hong, J. H., Yang, X., Chung, K. S. "Failure Performance Analysis of Resistance Spot Welded Advanced High Strength Steel Sheets", Key Engineering Materials, 651-653, pp. 895-900, 2015.

https://doi.org/10.4028/www.scientific.net/KEM.651-653.895

[102] Liu, R., Rao, M., Liu, S., Zhang, J., Luo, G. "Resistance Spot Welding Process and Properties of Hot Dip Galvanized DP590 High Strength Steel", In: Han, Y. (ed.) Advances in Materials Processing, CMC 2017, Springer, Singapore, Singapore, 2018, pp. 743-749. https://doi.org/10.1007/978-981-13-0107-0_71

[103] Russo Spena, P., De Maddis, M., Lombardi, F., D'Aiuto, F. "Resistance Spot Welding of Advanced High Strength TWIP Steels", Applied Mechanics and Materials, 423-426, pp. 876-880, 2013. https://doi.org/10.4028/www.scientific.net/AMM.423-426.876
[104] Borhy, I., Tóth, T.K. "Termomechanikusan hengerelt nagyszilárdságú acélok ellenállás ponthegesztési technológiájának optimalizálása" (Optimisation of resistance spot welding technology for thermomechanically rolled high strength steels), Hegesztéstechnika, 29(4), pp. 47-51, 2018. (in Hungarian)

[105] He, L., DiGiovanni, C., Han, X., Mehling, C., Wintjes, E., Biro, E., Zhou, N. Y. "Suppression of liquid metal embrittlement in resistance spot welding of TRIP steel", Science and Technology of Welding and Joining, pp. 579-586, 2019. https://doi.org/10.1080/13621718.2019.1573011

[106] Kishore, K., Kumar, P., Mukhopadhyay, G. "Resistance spot weldability of galvannealed and bare DP600 steel", Journal of Materials Processing Technology, 271, pp. 237-248, 2019. https://doi.org/10.1016/j.jmatprotec.2019.04.005

[107] Wintjes, E., DiGiovanni, C., He, L., Biro, E., Zhou, N. Y. "Quantifying the link between crack distribution and resistance spot weld strength reduction in liquid metal embrittlement susceptible steels", Welding in the World, 63, pp. 807-814, 2019. https://doi.org/10.1007/s40194-019-00712-5

[108] Hwang, I., Yun, H., Yoon, J., Kang, M., Kim, D., Kim, Y.-M. "Prediction of Resistance Spot Weld Quality of $780 \mathrm{MPa}$ Grade Steel Using Adaptive Resonance Theory Artificial Neural Networks", Metals, 8(6), Article No. 453, 2018. https://doi.org/10.3390/met8060453

[109] Ordoñez, J. H., Ambriz, R. R., García, C., Plascencia, G., Jaramillo D. "Overloading effect on the fatigue strength in resistance spot welding joints of a DP980 steel", International Journal of Fatigue, 121, pp. 163-171, 2019. https://doi.org/10.1016/j.ijfatigue.2018.12.026

[110] Zhao, D., Wang, Y., Zhang, P., Liang, D. "Modeling and Experimental Research on Resistance Spot Welded Joints for Dual-Phase Steel", Materials, 12(7), Article No. 1108, 2019. https://doi.org/10.3390/ma12071108

[111] Jia, Q., Liu, L., Guo, W., Peng, Y., Zou, G., Tian, Z., Zhou, N. Y. "Microstructure and Tensile-Shear Properties of Resistance SpotWelded Medium Mn Steel", Metals, 8(1), p. 48, 2018. https://doi.org/10.3390/met8010048

[112] Qiao, Z., Li, H., Li, L., Ran, X., Feng, L. "Microstructure and Properties of Spot Welded Joints of Hot-Stamped Ultra-High Strength Steel Used for Automotive Body Structures", Metals, 9(3), Article No. 285, 2019. https://doi.org/10.3390/met9030285

[113] Colombo, T. C. A., Rego, R. R., Otubo, J., de Faria, A. R. "Mechanical reliability of TWIP steel spot weldings", Journal of Materials Processing Technology, 266, pp. 662-674, 2019. https://doi.org/10.1016/j.jmatprotec.2018.11.021

[114] Paveebunvipak, K., Uthaisangsuk, V. "Characterization of Static Performance and Failure of Resistance Spot Welds of High-Strength and Press-Hardened Steels", Journal of Materials Engineering and Performance, 28(4), pp. 2017-2028, 2019. https://doi.org/10.1007/s11665-019-03988-2

[115] Aghajani, H., Pouranvari, M. "A pathway to produce strong and tough martensitic stainless steels resistance spot welds", Science and Technology of Welding and Joining, 24(3), pp. 185-192, 2019. https://doi.org/10.1080/13621718.2018.1483065 
[116] Li, S., Yang, S., Lu, Q., Luo, H., Tao, W. "A Novel Shim-Assisted Resistance Spot Welding Process to Improve Weldability of Medium-Mn Transformation-Induced Plasticity Steel", Metallurgical and Materials Transactions B, 50(1), pp. 1-9, 2019. https://doi.org/10.1007/s11663-018-1463-9

[117] Tumuluru, M. "4 - Resistance spot welding techniques for advanced high-strength steels* (AHSS)", In: Shome, M., Tumuluru, M. (eds.) Welding and Joining of Advanced High Strength Steels (AHSS), Woodhead Publishing, Sawston, UK, 2015, pp. 55-70. https://doi.org/10.1016/B978-0-85709-436-0.00004-7

[118] Ighodaro, O. L., Biro, E., Zhou, Y. N. "Comparative effects of Al-Si and galvannealed coatings on the properties of resistance spot welded hot stamping steel joints", Journal of Materials Processing Technology, 236, pp. 64-72, 2016. https://doi.org/10.1016/j.jmatprotec.2016.03.021

[119] Mei, L., Yi, J., Yan, D., Liu, J., Chen, G. "Comparative study on $\mathrm{CO}_{2}$ laser overlap welding and resistance spot welding for galvanized steel", Materials \& Design, 40, pp. 433-442, 2012. https://doi.org/10.1016/j.matdes.2012.04.014

[120] Long, X., Khanna, S. K. "Fatigue properties and failure characterization of spot welded high strength steel sheet", International Journal of Fatigue, 29(5), pp. 879-886, 2007. https://doi.org/10.1016/j.ijfatigue.2006.08.003

[121] Dancette, S., Fabrègue, D., Massardier, V., Merlin, J., Dupuy, T., Bouzekri, M. "Investigation of the Tensile Shear fracture of Advanced High Strength Steel spot welds", Engineering Failure Analysis, 25, pp. 112-122, 2012. https://doi.org/10.1016/j.engfailanal.2012.04.009

[122] Chen, R., Lou, M., Li, Y., Carlson, B. E. "Improving weldability of Al-Si coated press hardened steel using stepped current pulse schedule", Journal of Manufacturing Processes, 48, pp. 31-43, 2019. https://doi.org/10.1016/j.jmapro.2019.10.010

[123] Chabok, A., van der Aa, E., Pei, Y. "A study on the effect of chemical composition on the microstructural characteristics and mechanical performance of DP1000 resistance spot welds", Materials Science and Engineering: A, 788, Article No. 139501, 2020. https://doi.org/10.1016/j.msea.2020.139501

[124] Sobhani, B.S., Pouranvari, M. "Duplex Stainless Steel/Martensitic Steel Dissimilar Resistance Spot Welding: MicrostructureProperties Relationships", Welding Journal, 98, pp. 263-272, 2019.

[125] Sun, X., Zhang, Q., Wang, S., Han, X., Li, Y., David, S.A. "Effect of adhesive sealant on resistance spot welding of $301 \mathrm{~L}$ stainless steel", Journal of Manufacturing Processes, 51, pp. 62-72, 2020. https://doi.org/10.1016/j.jmapro.2020.01.033

[126] Ertek Emre, H., Bozkurt, B. "Effect of Cr-Ni coated Cu-Cr-Zr electrodes on the mechanical properties and failure modes of TRIP800 spot weldments", Engineering Failure Analysis, 110, Article No. 104439, 2020.

https://doi.org/10.1016/j.engfailanal.2020.104439

[127] Son, S. G., Hwang, Y., Lee, C. W., Yoo, J. H., Choi, M. "Effect of Hot Stamping Heat Treatment Temperature on Resistance Spot Weldability of Al-10\% Si Coated 30MnB5 Steel", Korean Journal of Metals and Materials, 57(12), pp. 778-786, 2019.

https://doi.org/10.3365/KJMM.2019.57.12.778
[128] Aydın, H., Tutar, M., Davut, K., Bayram, A. "Elektrik direnç punta kaynağı ile birleştirilen \%15 deforme edilmiş TWIP çeliğinde kaynak akımının mikroyapı ve mekanik özellikler üzerindeki etkisi" (Effect of welding current on microstructure and mechanical properties of $15 \%$ deformed TWIP steel joined with electrical resistance spot welding), Journal of the Faculty of Engineering and Architecture of Gazi University, 35(2), pp. 803-817, 2020. (in Turkish) https://doi.org/10.17341/gazimmfd.530292

[129] Pizzorni, M., Lertora, E., Mandolfino, C., Gambaro, C. "Experimental investigation of the static and fatigue behavior of hybrid ductile adhesive-RSWelded joints in a DP 1000 steel", International Journal of Adhesion and Adhesives, 95, Article No. 102400, 2019. https://doi.org/10.1016/j.ijadhadh.2019.102400

[130] Subrammanian, A., Senthiil, P. V., Jabaraj, D. B., Devakumar, D. "Improving mechanical performance of resistance spot welded joints of AISI 409M steel by double pulse current", Materials Today: Proceedings, 16(Part 2), pp. 949-955, 2019. https://doi.org/10.1016/j.matpr.2019.05.181

[131] Sivaraj, P., Seeman, M., Kanagarajan, D., Seetharaman, R. "Influence of welding parameter on mechanical properties and microstructural features of resistance spot welded dual phase steel sheets joint", Materials Today: Proceedings, 22(Part 3), pp. 558562,2020 .

https://doi.org/10.1016/j.matpr.2019.08.201

[132] Shah, U. H., Liu, X. "Ultrasonic resistance welding of TRIP-780 steel", Journal of Materials Processing Technology, 274, Article No. 116287, 2019. https://doi.org/10.1016/j.jmatprotec.2019.116287

[133] Sun, X., Stephens, E. V., Khaleel, M. A. "Effects of fusion zone size and failure mode on peak load and energy absorption of advanced high strength steel spot welds under lap shear loading conditions", Engineering Failure Analysis, 15(4), pp. 356-367, 2008. https://doi.org/10.1016/j.engfailanal.2007.01.018

[134] Ren, D., Zhao, D., Zhao, K., Liu, L., He, Z. "Resistance ceramic-filled annular welding of DP980 high-strength steel", Materials \& Design, 183, Article No. 108118, 2019. https://doi.org/10.1016/j.matdes.2019.108118

[135] Ghatei Kalashami, A., Han, X., Goodwin, F., Zhou, N. Y. "The influence of modified annealing during the galvanizing process on the resistance spot welding of the CMn1.8Si advanced high strength steel", Surface and Coatings Technology, 381, Article No. 125181, 2020. https://doi.org/10.1016/j.surfcoat.2019.125181

[136] Mohamadizadeh, A., Biro, E., Worswick, M., Zhou, N., Malcolm, S., Yau, C., Jiao, Z., Chan, K. "Spot Weld Strength Modeling and Processing Maps for Hot-Stamping Steels", Welding Journal, 98, pp. 241-249, 2019.

https://doi.org/10.29391/2019.98.021

[137] Vijayan, V., Murugan, S. P., Son, S.-G., Park, Y.-D. "Shrinkage Void Formation in Resistance Spot Welds: Its Effect on Advanced High-Strength-Steel Weld Strength and Failure Modes", Journal of Materials Engineering and Performance, 28(12), pp. 7514 7526, 2019. https://doi.org/10.1007/s11665-019-04465-6 
[138] Chao, Y.J. "Ultimate Strength and Failure Mechanism of Resistance Spot Weld Subjected to Tensile, Shear, or Combined Tensile/Shear Loads", Journal of Engineering Materials and Technology, 125(2), pp. 125-132, 2003. https://doi.org/10.1115/1.1555648

[139] Qi, L., Li, F., Chen, R., Zhang, Q., Li, Y. "Improve resistance spot weld quality of advanced high strength steels using bilateral external magnetic field", Journal of Manufacturing Processes, 52, pp. 270-280, 2020

https://doi.org/10.1016/j.jmapro.2020.02.030

[140] Varbai, B., Pickle, T., Májlinger, K. "Effect of heat input and role of nitrogen on the phase evolution of 2205 duplex stainless steel weldment", International Journal of Pressure Vessels and Piping, 176, Article No. 103952, 2019. https://doi.org/10.1016/j.ijpvp.2019.103952

[141] Vargas Cortés, V.H., Altamirano Guerrero, G., Mejía Granados, I., Baltazar Hernández, V.H., Maldonado Zepeda, C. "Effect of Retained Austenite and Non-Metallic Inclusions on the Mechanical Properties of Resistance Spot Welding Nuggets of Low-Alloy TRIP Steels", Metals, 9(10), Article No. 1064, 2019. https://doi.org/10.3390/met9101064

[142] Chtourou, R., Leconte, N., Chaari, F., Haugou, G., Markiewicz, É., Zouari, B. "Macro-modeling of the strength and failure of multilayer multi-steel grade spot welds: Connector formulation, assembly model and identification procedure", Thin-Walled Structures, 113 , pp. 228-239, 2017 https://doi.org/10.1016/j.tws.2017.01.023

[143] Chen, J., Yuan, X., Hu, Z., Li, T., Wu, K., Li, C. "Improvement of resistance-spot-welded joints for DP 600 steel and A5052 aluminum alloy with $\mathrm{Zn}$ slice interlayer", Journal of Manufacturing Processes, 30, pp. 396-405, 2017. https://doi.org/10.1016/j.jmapro.2017.10.009

[144] Den Uijl, N., Smith, S., Moolevliet, T., Goos, C., Van der Aa, E. M., Van der Veldt T. "Failure modes of resistance spot welded advanced high strength steels", In: The 5th International Seminar on Advances in Resistance Welding, Toronto, Canada, 2008, pp. 78-104. https://doi.org/10.13140/RG.2.1.1321.8165

[145] Russo Spena, P., Rossi, S., Wurzer, R. "Effects of Welding Parameters on Strength and Corrosion Behavior of Dissimilar Galvanized Q\&P and TRIP Spot Welds", Metals, 7(12), Article No. 534, 2017.

https://doi.org/10.3390/met7120534

[146] Russo Spena, P., De Maddis ,M., Lombardi, F. "Mechanical Strength and Fracture of Resistance Spot Welded Advanced High Strength Steels", Procedia Engineering, 109, pp. 450-456, 2015. https://doi.org/10.1016/j.proeng.2015.06.262

[147] Onar, V., Aslanlar, S., Akkaş, N. "Effect of welding current on mechanical properties of welding joints in TRIP 800 and micro alloyed steels in resistance spot welding", In: 4th International Conference on Welding Technologies and Exhibition (ICWET'16), Gaziantep, Turkey, 2016, pp. 1-6.

[148] Pouranvari, M., Mousavizadeh, S. M., Marashi, S. P. H., Goodarzi, M., Ghorbani, M. "Influence of fusion zone size and failure mode on mechanical performance of dissimilar resistance spot welds of AISI 1008 low carbon steel and DP600 advanced high strength steel", Materials \& Design, 32(3), pp. 1390-1398, 2011.

https://doi.org/10.1016/j.matdes.2010.09.010
[149] Noh, W., Kim, W., Yang, X., Kang, M., Lee, M.-G., Chung, K. "Simple and effective failure analysis of dissimilar resistance spot welded advanced high strength steel sheets", International Journal of Mechanical Sciences, 121, pp. 76-89, 2017. http://doi.org/10.1016/j.ijmecsci.2016.12.006

[150] Yuan, X., Li, C., Chen, J., Li, X., Liang, X., Pan, X. "Resistance spot welding of dissimilar DP600 and DC54D steels", Journal of Materials Processing Technology, 239, pp. 31-41, 2017. https://doi.org/10.1016/j.jmatprotec.2016.08.012

[151] Huin, T., Dancette, S., Fabrégue, D., Dupuy, T. "Investigation of the Failure of Advanced High Strength Steels Heterogeneous Spot Welds", Metals, 6(5), pp. 111-130, 2016. https://doi.org/10.3390/met6050111

[152] Russo Spena, P., De Maddis, M., D'Antonio, G., Lombardi, F. "Weldability and Monitoring of Resistance Spot Welding of Q\&P and TRIP Steels", Metals, 6(11), pp. 270-285, 2016. https://doi.org/10.3390/met6110270

[153] Russo Spena, P., Cortese, L., De Maddis, M., Lombardi, F. "Effects of Process Parameters on Spot Welding of TRIP and Quenching and Partitioning Steels", steel research international, 87(12), pp. 1592-1600, 2016. https://doi.org/10.1002/srin.201600007

[154] Choi, H.-S., Park, G.-H., Lim, W.-S., Kim, B.-m. "Evaluation of weldability for resistance spot welded single-lap joint between GA780DP and hot-stamped 22MnB5 steel sheets", Journal of Mechanical Science and Technology, 25(6), Article No. 1543, 2011. https://doi.org/10.1007/s12206-011-0408-x

[155] Kim, D., Yu, J., Rhee, S. "Effect of a conically shaped hollow electrode on advanced high strength steel in three-sheet resistance spot welding", International Journal of Precision Engineering and Manufacturing, 17(3), pp. 331-336, 2016. https://doi.org/10.1007/s12541-016-0041-9

[156] Zhang, H., Qiu, X., Bai, Y., Xing, F., Yu, H., Shi, Y. "Resistance spot welding macro characteristics of the dissimilar thickness dual phase steels", Materials \& Design, 63, pp. 151-158, 2014. https://doi.org/10.1016/j.matdes.2014.05.060

[157] Alizadeh-Sh, M., Marashi, S. P. H. "Resistance spot welding of dissimilar austenitic/duplex stainless steels: Microstructural evolution and failure mode analysis", Journal of Manufacturing Processes, 28(Part 1), pp. 186-196, 2017. https://doi.org/10.1016/j.jmapro.2017.06.005

[158] Jaber, H., Kovacs, T. "Dissimilar Resistance Spot Welding of Ferrite-Martensite Dual Phase Steel/Low Carbon Steel: Phase Transformations and Mechanical Properties", In: Jármai, K., Bolló, B. (eds.) Vehicle and Automotive Engineering 2, Lecture notes in Mechanical Engeneering, Springer International Publishing, Cham, Switzerland, 2018, pp. 709-718. https://doi.org/10.1007/978-3-319-75677-6_60

[159] Mousavi Anijdan, S. H., Sabzi, M., Ghobeiti-Hasab, M., RoshanGhiyas, A. "Optimization of spot welding process parameters in dissimilar joint of dual phase steel DP600 and AISI 304 stainless steel to achieve the highest level of shear-tensile strength", Materials Science and Engineering: A, 726, pp. 120-125, 2018. https://doi.org/10.1016/j.msea.2018.04.072 
[160] Vignesh, K., Elaya Perumal, A., Velmurugan, P. "Optimization of resistance spot welding process parameters and microstructural examination for dissimilar welding of AISI $316 \mathrm{~L}$ austenitic stainless steel and 2205 duplex stainless steel", The International Journal of Advanced Manufacturing Technology, 93(1), pp. 455-465, 2017. https://doi.org/10.1007/s00170-017-0089-4

[161] Ozturk Yilmaz, I., Bilici, A. Y., Aydin, H. "Microstructure and mechanical properties of dissimilar resistance spot welded DP1000-QP1180 steel sheets", Journal of Central South University, 26(1), pp. 25-42, 2019.

https://doi.org/10.1007/s11771-019-3980-3

[162] Vignesh, K., Elaya Peruma,1 A., Velmurugan, P. "Resistance spot welding of AISI-316L SS and 2205 DSS for predicting parametric influences on weld strength - Experimental and FEM approach", Archives of Civil and Mechanical Engineering, 19(4), pp. 10291042, 2019.

https://doi.org/10.1016/j.acme.2019.05.002

[163] Liu, C., Zheng, X., He, H., Wang, W., Wei, X. "Effect of work hardening on mechanical behavior of resistance spot welding joint during tension shear test", Materials \& Design, 100, pp. 188-197, 2016. https://doi.org/10.1016/j.matdes.2016.03.120

[164] Özsarac, U., Onar, V., Özen, F., Aslanlar, Y.S., Akkaş, N., Aslan, H., Aslanlar, S. "Effect of welding time on tensile-shear load in resistance spot welded TRIP 800 and microalloyed steels", Indian Journal of Chemical Technology 26(4), pp. 355-357, 2019. http://nopr.niscair.res.in/handle/123456789/49684
[165] Janardhan, G., Kishore, K., Mukhopadhyay, G., Dutta, K. "Fatigue Properties of Resistance Spot Welded Dissimilar InterstitialFree and High Strength Micro-Alloyed Steel Sheets", Metals and Materials International, 27, pp. 3432-3448, 2021. https://doi.org/10.1007/s12540-020-00678-w

[166] Jia, Q., Liu, L., Guo, W., Peng, Y., Zou, G., Tian, Z., Zhou, Y. N. "Microstructure and Tensile-Shear Properties of Resistance SpotWelded Medium Mn Steel", Metals, 8(1), Article No. 48, 2018. https://doi.org/10.3390/met 8010048

[167] American Welding Society "AWS D8.1M:2013 - Specification for Automotive Weld Quality - Resistance Spot Welding of Steel", American Welding Society, Doral, FL, USA, 2013.

[168] International SOrganization for Standardization "ISO 14373:2015(en) Resistance welding -. Procedure for spot welding of uncoated and coated low carbon steels", The International SOrganization for Standardization, Geneva, Switzerland, 2015.

[169] Draper, N. R. "Introduction to Box and Wilson (1951) On the Experimental Attainment of Optimum Conditions", In: Kotz, S., Johnson, N. L. (eds), Breakthroughs in Statistics, Springer, New York, NY, USA, pp. 267-269.

https://doi.org/10.1007/978-1-4612-4380-9_22 